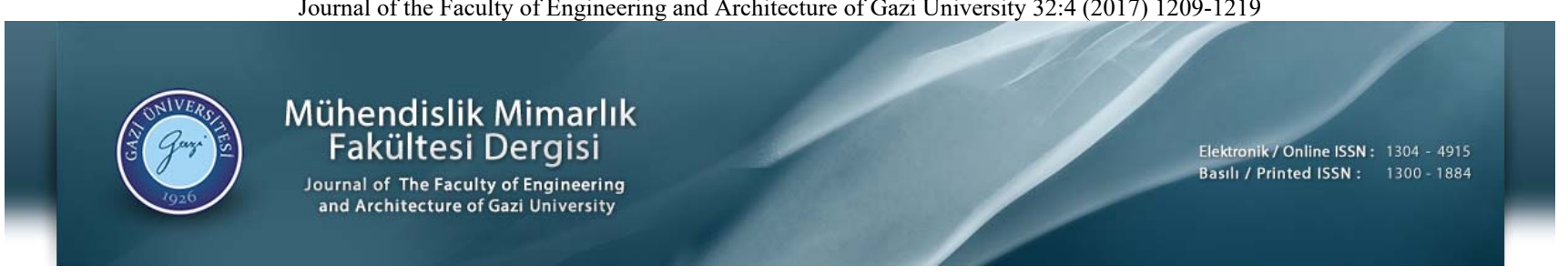

\title{
Reaktif organobentonit katkıların sert poliüretan köpügün bazı performans özellikleri üzerine etkisi
}

\author{
Murat Erdem*(i), Kübra Ortaç (iD), Bilge Erdem ${ }^{(D)}$, Hayrettin Türk (D) \\ Anadolu Üniversitesi, Fen Fakültesi, Kimya Bölümü, Yunus Emre Kampüsü, 26470, Eskişehir, Türkiye
}

Ö N E Ç I K A N L A R

- Organobentonit katkılı sert poliüretan köpük nanokompozit sentezi

- Katk1 türü ve miktarının köpüğün 1sıl iletkenliği üzerine etkisi

- Köpüğün basma mukavemeti ile katkı türü ve miktarı arasındaki ilişki

Makale Bilgileri

Geliș: 12.06.2017

Kabul: 17.09.2017

DOI:

Anahtar Kelimeler:

Sert poliüretan köpük,

bentonit,

nanokompozit,

ssl iletkenlik,

basma mukavemeti

\section{ÖZET}

Bu çalışmada; bentonit, amin ve hidroksil fonksiyonelliğine sahip bileşikler ile modifiye edilmiş ve elde edilen organobentonitler sert poliüretan köpük nanokompozit (SPKN) sentezinde katk1 olarak kullanılmışlardır. Poliüretan matrikste kil tabakalarının dağılımı dar açılı X-ışını kırınım cihazı kullanılarak incelenmiştir. Köpüklerin yüzey morfolojileri taramalı elektron mikroskobu ile incelenmiş, kapalı hücre içerikleri gaz yer değiştirmeli piknometre kullanılarak belirlenmiş, isıl iletkenlikleri 1sı akış metre cihazı, basma mukavemetleri ise üniversal test cihazı kullanılarak ölçülmüştür. Katkı türünün ve miktarının köpüğün ortalama hücre boyutu, kapalı hücre içeriği, 1sıl iletkenliği, yoğunluğu ve basma mukavemeti üzerine etkileri araştırılmıştır. Elde edilen SPKN'lerin ortalama hücre boyutu ve isıl iletkenlik değerlerinde katkı içermeyen sert poliüretan köpüğe (SPK) kıyasla azalma gözlenirken, kapalı hücre içeriği ve yoğunluk değerlerinde artış tespit edilmiştir. Katkılama ile birlikte poliüretan köpüğün ısıl iletkenliği yaklaşı \%10 mertebesinde azalmıştır. \%1 katkı içeren tüm SPKN'ler için basma mukavemeti değerleri SPK'ye kıyasla yüksek olmuş, katkı miktarındaki artış ile birlikte mukavemet değerleri genellikle düşmüştür.

\section{Effect of reactive organobentonite additives to the some performance properties of rigid polyurethane foam}

\section{H I G H L I G H T S}

- The synthesis of rigid polyurethane foam nanocomposites containing organobentonites

- The effect of additive type and amount on the thermal conductivity of the foam

- The relationship between the compressive strength of the foam and type and amount of the additive

Article Info

Received: 12.06 .2017

Accepted: 17.09 .2017

DOI:

Keywords:

Rigid polyurethane foam, bentonite, nanocomposite, thermal conductivity, compressive strength.

\section{ABSTRACT}

In this study, bentonite was modified with the compounds which have amine and hydroxyl functionality and obtained organobentonites were used as additive for the synthesis of rigid polyurethane foam nanocomposites (SPKN). The dispersion of clay layers into the polyurethane matrix was investigated using a small angle X-ray diffractometer. A Scanning electron microscope, a gas pycnometer, a heat flow meter and a universal test machine were used for the morphological characterization, closed cell content, thermal conductivity and compressive strength of the foams, respectively. The effects of additive type and amount on the average cell size, closed cell content, thermal conductivity, density and compressive strength of the foam were investigated. For all nanocomposites, the average cell size and the thermal conductivity were lower than those of rigid polyurethane foam (SPK), while closed cell content and density were higher. In the presence of organobentonite, the thermal conductivity of the foam was reduced by about $10 \%$. While the compressive strength of nanocomposites containing $1 \%$ additive were higher than that of SPK, these values were generally decreased with the increasing amount of additive. 


\section{GÍRİŞ (INTRODUCTION)}

Dünyadaki nüfus artışı, sanayileşme ve kentleşme ile birlikte artan ticaret olanakları enerjiye olan talebi arttırmaktadır. Bu nedenle enerjinin insanoğlu için önemi her geçen gün daha belirgin hale gelmektedir. Diğer yandan artan talepler ile birlikte yakıt/enerji fiyatlarındaki yükseliş, enerji verimliliği ve tasarrufu konularını kritik unsurlar haline getirmiştir. Enerji verimliliği, tüketilen enerji miktarının, üretimdeki miktar ve kaliteyi düşürmeden, ekonomik kalkınmayı ve sosyal refahı engellemeden en aza indirilmesidir. Çıkan yasa ve yönetmeliklerle, yapılan uluslararası anlaşmalarla (Kyoto Protokolü vb.) zorunlu hale getirilen enerji verimliliğinde en önemli faktör enerji tasarrufudur. Enerji tasarrufu enerjiyi daha az tüketen teknolojiler kullanmak, alışkanlıkları ve günlük davranışları enerjiyi daha verimli kullanacak biçimde düzenlemek ve mevcut malların daha uzun süre kullanılmasını sağlamak gibi somut önlemler ile sağlanabilir. Kişi başına enerji tüketimi yüksek, enerji yoğunluğu düşük ülkeler arasında yer alan ülkemiz için enerji verimliliği ve tasarrufu dikkatle değerlendirilmesi ve planlanması gereken bir konudur. Toplumda enerji kültürü oluşturulması, verimlilik ve çevre konularında farkındalığın artırılarak tüketim alışkanlıklarının pozitif yönde değiştirilmesi amacıyla çeşitli faaliyetler de yürütülmektedir [1].

Enerji verimliliği denildiğinde akla ilk gelen olgulardan biri ıs1 yalıtımıdır. Tüm dünyada alternatif enerji kaynaklarının kullanımına yönelik çalışmalar hızla artmakla birlikte, en ucuz enerjinin korunan enerji olduğu da unutulmamalıdır. Is1 yalıtımı, enerjinin korunması noktasında kazanımlar sağlar ve 1S1 enerjisinin sıcak ortamdan soğuk ortama akışını minimum düzeye indirmek amaciyla yapılan bir uygulamadır. Cam yünü, genleştirilmiş polistiren (EPS), ekstrude polistiren (XPS), kalsiyum silikat, fenol köpüğü, poliüretan köpük günümüzde sıklıkla kullanılan 1sı yalıtım malzemeleridir. Bu malzemeler arasında poliüretan köpükler düşük 1sıl iletkenlikleri nedeniyle ön plana çıkmaktadırlar [2]. Poliüretanlar, polioller ile diizosiyanatların polikondenzasyon reaksiyonları sonucu oluşan yüksek mol kütleli polimerlerdir ve zincir yapılarında üretan (karbamat) köprüleri içerirler. Üretan köprüsü, izosiyanat ile hidroksil grupları arasındaki reaksiyon sonrasında oluşur [3]. Poliüretanlar; termoplastik, elastomer, köpük, boya, yapıştırıcı ve kauçuk yapımında sıklıkla kullanılırlar. Isı ve ses yalıtımı ise yalıtkan özellikli sert poliüretan köpüklerin önemli bir uygulama alanıdır [4]. Poliüretan polimer zincirlerinde bulunan izosiyanat gruplarının, ortamda bulunabilecek az miktar su ile reaksiyonu sonucunda karbondioksit gazı açığa çıkar ve bu gaz reaksiyon sürecinde artan ortam viskozitesi nedeniyle sistemden uzaklaşamaz, şişirici gaz olarak davranır ve köpük oluşumuna neden olur. $\mathrm{Su}$, bu reaksiyonda kimyasal şişirici ajan olarak davranır ve karbondioksit oluşumunu sağlar. Diğer yandan, kloroflorokarbonlar ve hidrokloroflorokarbonlar gibi düşük kaynama noktalı bileşikler de sert poliüretan köpüklerin eldesinde fiziksel şişirici ajan olarak davranırlar [5].
Reaksiyon sürecinde açığa çıkan 1sı ile birlikte fiziksel şişirici ajan buharlaşır ve köpük yapısı oluşur. Köpük oluşum sürecinin termodinamiği, şişirici ajanın poliüretan matriks içerisindeki çekirdeklenme ve büyüme mekanizmaları ile açıklanır [6]. Sert poliüretan köpükler, kapalı hücresel yapıları ve hücrelerin içerisinde hapsolan şişirme ajanının düşük 1sıl iletkenliği sayesinde mükemmel bir 1s1 yalıtımı sağlarlar [7]. Ayrıca, düşük yoğunluklu ve uzun ömürlü olmalarının yanında en düşük kalınlıkta en verimli yalıtım malzemesi olmaları, bu tür malzemeleri ilgili sektörlerde ön plana çıkarmaktadır. Diğer yandan, günümüzde köpüklerin yalıtım performanslarını daha da iyi hale getirmek için bilim dünyasında ve ilgili sektörlerde yoğun çabalar sarf edilmektedir. $\mathrm{Bu}$ noktada araştırmacıların yoğunlaştıkları temel yaklaşımlar, köpük yapısındaki hücrelerin boyutlarını küçültmek ve difüzyon bariyeri görevi yapabilecek çeşitli katkılar ile hücresel yapı içerisindeki şişirici gazın hücre dışına difüzyonunu engellemektir. Killer, bu amaçlar için kullanılabilecek nano boyutlu katkılardırlar ve şişirici gaz baloncuklarının heterojen çekirdeklenmelerine sebep olarak, yani çekirdeklenme ve büyüme mekanizmalarına etki ederek daha küçük boyuta sahip hücrelerin oluşumunu sağlarlar. Kil katkılama ile elde edilen SPKN'lerin 1s1l iletkenliklerinin SPK'ye kıyasla daha düşük olduğu görülmektedir [8]. Birçok çalışmada, mekanik ve ısıl dayanım özelliklerinin de kil katkılama ile birlikte genellikle iyileştiği ortaya konmuştur [9]. Ayrıca kilin SPKN'nin yanma davranışını da olumlu anlamda etkileyebildiği göze çarpmaktadır [10]. Killer, toprak ve kayaçlarda bulunan, doğal yollarla oluşmuş, ince taneli, su katıldığında plastik özelliği gösteren kristal yap1lı malzemelerdir. Kil mineralleri, belirli miktarlarda $\mathrm{Mg}$, $\mathrm{K}, \mathrm{Ca}, \mathrm{Na}$ ve $\mathrm{Fe}$ içeren hidratlaşmış aluminosilikatlardır ve bileşiminde iki boyutlu tekrar eden tetrahedral tabakalar içerirler. Kil mineralleri olarak yüksek oranda montmorillonit içeren maddelere bentonit adı verilmektedir. Bentonitler \% 75 veya daha fazla montmorillonit içermekle birlikte içinde safsızlık olarak kaolin ve illit gibi diğer kil mineralleri de bulundurmaktadırlar [11].

Bu çalışmada, bentonit ve organobentonit katkılama ile sert poliüretan köpügün bazı performans özelliklerinde meydana gelen değişimler incelenmiştir. Çalışmanın nihai hedefi, ısıl iletkenliği düşürülmüş olmasının yanısıra, basma mukavemeti de belirli seviyelerde tutulmuş/korunabilmiş SPKN'ler elde etmektir. Bentonitin modifikasyonu için amin fonksiyonelliğine sahip trietilamin (TEA, monofonksiyonel), N,N-dimetiloktilamin (DMOA, monofonksiyonel) ve N,N,N',N'-tetrametil-p-fenilendiamin (TMPPD, bifonksiyonel) ile hem hidroksil hem de amin fonksiyonelliklerine sahip tris(hidroksimetil)aminometan (TRIS, tetrafonksiyonel) bileşikleri kullanılmış ve bu şekilde reaktif mono-, bi- ve tetrafonksiyonel organobentonit yapıları elde edilmiştir. $\mathrm{Bu}$ yapılardaki reaktif amin ve hidroksil gruplarının izosiyanat bileşiği ile reaksiyona girerek inorganik bentonit yapısının organik özellikli poliüretan matriksinde dağlımını arttıracağı düşünülmüştür. Organobentonitlerin katkılanması ile elde edilen SPKN'ler eldelerin uygulamaya yönelik performansları hakkında bilgi 
elde edebilmek için bazı karakterizasyon çalışmaları yürütülmüştür. $\mathrm{Bu}$ noktada temel değerlendirme kriterleri olarak, çalışmanın daha önce ifade edilen temel amacına da uygun olarak is1l iletkenlik ve basma mukavemeti seçilmiştir. Bunların yanısıra, morfolojik karakterizasyon, kapalı hücre içeriği, ortalama hücre boyutu ve yoğunluk ölçümleri bahsi geçen bu kriterleri destekleyen diğer karakterizasyon çalışmaları olarak gerçekleştirilmiştir.

\section{DENEYSEL METOT (EXPERIMENTAL METHOD)}

\subsection{Kimyasallar (Chemicals)}

Poliol (DSD 459.01) ve polimerik MDI ([4,4'Metilenebis(fenil izosiyanat)], VORATEC SD100) Dow Chemicals firmasından temin edilmiştir. Bentonit Eczacıbaşı ESAN'dan, TEA, DMOA, TMPPD ve TRIS ise SigmaAldrich'den satın alınmıştır.

\subsection{Analizler ve Karakterizasyon Çalışmaları (Analyses and Characterization Studies)}

Bentonit ve organobentonitlerin fonksiyonel grup analizleri, karbon ve azot element içerikleri, temel tabaka aralıkları ve 1sıya karşı kütle kaybı davranışları sırasıyla fourier dönüşümlü infrared spektrometre (FTIR, Perkin Elmer Spectrum 100), elementel analiz (Vario III elementar), X1şını kırınım (XRD, Rigaku D-Max2200) ve termogravimetrik analiz (TGA, Seteram Labsys) cihazları ile yapılmıştır/belirlenmiştir. Katkıların poliüretan matriks içerisindeki dağılımı dar açılı X-ışını kırınım (SAXS, Bruker D8 Advance) cihazı kullanılarak araştırılmıştır. Köpüklerin yüzey morfolojileri taramalı elektron mikroskobu (SEM, Carl Zeiss Ultra Plus) ile incelenmiş, kapalı hücre içerikleri gaz yer değiştirmeli piknometre (Micromeritics AccuPyc II 1340) kullanılarak belirlenmiş, 1sıl iletkenlikleri 1sı akış metre cihazı (Linseis HFM 300) kullanılarak ölçülmüş, basma mukavemetleri ise üniversal test cihazı (Zwick Roell Z010) ile incelenmiştir. Köpükler, $30 \times 30 \times 10 \mathrm{~cm}^{3}$ (en $\times$ boy $\times$ derinlik) hacme sahip bir su sirkülasyonlu kalıp sistemi kullanılarak kalıplanmıştır. Kalıptan çıkarılan köpüklerin istenilen ebatlarda kesilerek tüm yüzeylerinin tıraşlanması/düzlenmesi için ise köpük kesme/yüzey düzleme makinası kullanılmıştır. Katkıların poliol içerisinde dağıtılması için sırasıyla mekanik karıştırıcı (IKA RW16) ve yüksek hızlı karıştırıcı (Silverson L5M) kullanılmıştır.

\subsection{Bentonit Modifikasyonu (Modification of Bentonite)}

Modifikasyon süreçleri, bentonitin katyon değişim kapasitesinin (KDK, $76 \mathrm{mmol} / 100 \mathrm{~g}$ ) molce 1,5 kat1 modifikasyon bileşiği kullanılarak, Tyan vd.'nin [12] montmorilloniti $p$-fenilendiamin ile modifiye ettikleri çalışmaya benzer biçimde, iyon değişimi mekanizması üzerinden gerçekleştirilmiştir. TRIS ile modifikasyon süreci şu şekilde yürütülmüştür: Uygun miktarda TRIS $500 \mathrm{~mL}$ saf suda çözülmüş, elde edilen çözelti bir miktar 0,01 N HCl ile asitlendirilmiştir. Ardından bu çözeltiye 10 gram bentonit ilave edilmiş, karışım $60^{\circ} \mathrm{C}^{\prime}$ de 3 saat boyunca mekanik olarak karıştırılmıştır. Elde edilen organobentonit, kaba filtre kağıdından süzülerek karışımdan ayrılmış, bol miktarda saf su ile yıkanmış ve $80^{\circ} \mathrm{C}^{\prime}$ lik etüvde 24 saat boyunca kurutulmuş ve B-TRIS olarak kodlanmıştır. TEA, DMOA ve TMPPD ile modifikasyon süreçleri de benzer biçimde gerçekleştirilmiş, elde edilen yapılar sırasıyla B-TEA, BDMOA ve B-TMPPD olarak isimlendirilmiştir.

\subsection{Sert Poliüretan Köpük (SPK) ve Sert Poliüretan Köpük Nanokompozit (SPKN) Sentezi \\ (Synthesis of Rigid Polyurethane Foam and Rigid Polyurethane Foam Nanocomposite)}

İlk aşamada 1,0 L'lik polipropilen bardağa poliol konmuş, karışım mekanik karıştırıcı ile kısa bir süre karıştırılmıştır. Ardından üzerine polimerik MDI eklenmiştir. Yaklaşık 5 saniye içerisinde şişmeye başlayan köpük, sıcaklığ $37^{\circ} \mathrm{C}$ $\left( \pm 2^{\circ} \mathrm{C}\right)$ sabitlenmiş kalıba hızla dökülmüş ve kapalı kalıpta 5 dakika boyunca kürlenmeye bırakılmıştır. Kalıptan çıkarılan köpük yan kesme ve yüzey düzleme makinası yardımıyla yaklaşık $30 \times 30 \times 4 \quad($ en $\times$ boy $\times$ yükseklik $) \quad$ boyutlarına getirilmiştir. SPKN'lerin sentezi de SPK üretimine benzer şekilde yapılmıştır. Uygun miktarda katkı içeren poliol bir süre mekanik karıştırıcı ve ardından yüksek hızlı karıştırıcı kullanılarak 5000 devir/dakika hızda 2 dakika boyunca karıştırılmıştır. Polimerik MDI'nın karışıma ilavesinin ardından süreç SPK üretimine benzer biçimde devam ettirilmiştir. Sonuç olarak poliol'e göre kütlece $\% 1, \% 3, \% 5$ ve \% 7 katkı içeren SPKN'ler elde edilmiştir.

\section{SONUÇLAR VE TARTIŞMALAR (RESULTS AND DISCUSSIONS)}

\subsection{Bentonit ve Organobentonitlere İlişkin Karakterizasyon Çalışmaları \\ (Characterization Studies of Bentonite and Organobentonites)}

XRD, killer gibi kristal yapılı/tabakalı malzemelerde tabaka aralık değerlerinin belirlenmesinde kullanılan önemli bir yöntemdir. Şekil 1'de bentonit ve organobentonitler için XRD desenleri ve temel tabaka aralık değerleri $\left(\mathrm{d}_{001}\right)$ verilmiştir. 12,5 Å olan bentonite ilişkin $\mathrm{d}_{001}$ değerinin TEA, DMOA, TMPPD ve TRIS ile modifikasyon sonrasinda sırasıyla, $13,5,13,1,14,8$ ve $20,4 \AA$ değerlerine yükseldiğ $i$ görülmüştür. Sadece amin fonksiyonelliği içeren bileşikler kendi içerisinde değerlendirildiğinde TMPPD'nin TEA ve DMOA'ya kıyasla $\mathrm{d}_{001}$ değerini daha çok arttırdığ görülmektedir. $\mathrm{Bu}$ durumun ortaya çıkmasına TMPPD'nin daha büyük molekül boyutunun neden olabileceği düşünülmektedir. DMOA ile sağlanan $\mathrm{d}_{001}$ değerinin TEA ile sağlanandan, beklentilerin aksine küçük olması ise DMOA moleküllerinin tabakalar arasından ziyade tabaka yüzeylerine tutunmuş olabileceğini düşündürmektedir. Diğer yandan, TRIS ile modifikasyon sonrası gözlenen 20,4 Å'lük nispeten yüksek $\mathrm{d}_{001}$ değerinin, yapıdaki iki farklı tür fonksiyonelliğin yanı sıra bu fonksiyonelliklerin sayısının da etkisinin olduğu tahmin edilmektedir. Azzouz vd. [13], 2013 yılından yayımlamış oldukları çalışmada, Namontmorilloniti TRIS ile doğal $\mathrm{pH}$ değerindeki sulu ortamda

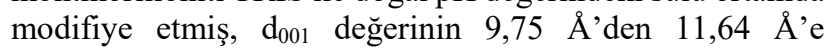


yükseldiğini gözlemlemişlerdir. $\mathrm{Bu}$ sonuç, asitlendirilmiş ortamda yapılacak modifikasyonun kil yapısına ait tabaka aralık değerini daha etkin biçimde arttırabildiğini ortaya koyması bakımından önemlidir. Şekil 2'de ise, bentonit ve organobentonitler ait FTIR spektrumları verilmiştir. Bentonite ilişkin karakteristik bantlar şu şekilde ifade edilebilir: $3626 \mathrm{~cm}^{-1}$ 'de $\mathrm{Si}-\mathrm{O}$ yüzeyine hidrojen bağı ile bağlı su moleküllerine ait $\mathrm{H}-\mathrm{O}-\mathrm{H}$ gerilim titreşim bandı, $3443 \mathrm{~cm}^{-1}$, de adsorplanan su moleküllerine ilişkin bant, $1632 \mathrm{~cm}^{-1}$, de sudaki -OH grubuna ait deformasyon band1, $1085 \mathrm{~cm}^{-1}$ ve $1039 \mathrm{~cm}^{-1}$, de tetrahedral tabakadaki Si-O-Si gruplarının $\mathrm{Si}-\mathrm{O}$ gerilim titreşimiyle ilgili bantlar, 521 ile $467 \mathrm{~cm}^{-1}$ 'de sirasiyla oktahedral $\mathrm{Si}-\mathrm{O}-\mathrm{Al}$ ve $\mathrm{Si}-\mathrm{O}-\mathrm{Si}$ bükülme titreşimlerine ilişkin bantlar [11]. B-TEA için, 2490-3000 $\mathrm{cm}^{-1}$ arasında ortaya çıkan yeni bantların $-\mathrm{CH}_{2}-$ gruplarının gerilme titreşimlerinden ait olduğu düşünülmektedir. Ayrıca, 1350-1480 $\mathrm{cm}^{-1}$ arasında yer alan bantlar -C-H eğilme titreşimlerinden kaynaklanmaktadır. BDMOA'ya ilişkin FTIR spektrumlarında, $2800 \mathrm{~cm}^{-1}$ ile 3000 $\mathrm{cm}^{-1}$ aralığında görülen bantlar $-\mathrm{CH}_{2}-$ gruplarının simetrik ve antisimetrik eğilmelerine işaret etmektedir. Yaklaşı 1450 $\mathrm{cm}^{-1}$ 'de gözlenen bant yine B-TEA'ya benzer biçimde $-\mathrm{C}-$ $\mathrm{H}$ eğilme titreşimlerinin varlığını göstermektedir. B-TMPPD için $1520 \mathrm{~cm}^{-1}$ ve $1655 \mathrm{~cm}^{-1}$, deki bantlar aromatik halkanın varlığını göstermesi bakımından önemlidir. Diğer yandan, B-TRIS yapısına ilişkin spektrum incelendiğinde 2850-3000 $\mathrm{cm}^{-1}$ aralığında görülen pikler, $-\mathrm{CH}_{2}-$ gruplarının varlığına ilişkin bir kanıt olarak değerlendirilebilir. Elementel analiz sonuçlarından $100 \mathrm{~g}$ organobentonit başına \%azot miktarları TEA, DMOA, TMPPD ve TRIS için sirasılyla \%0,664,

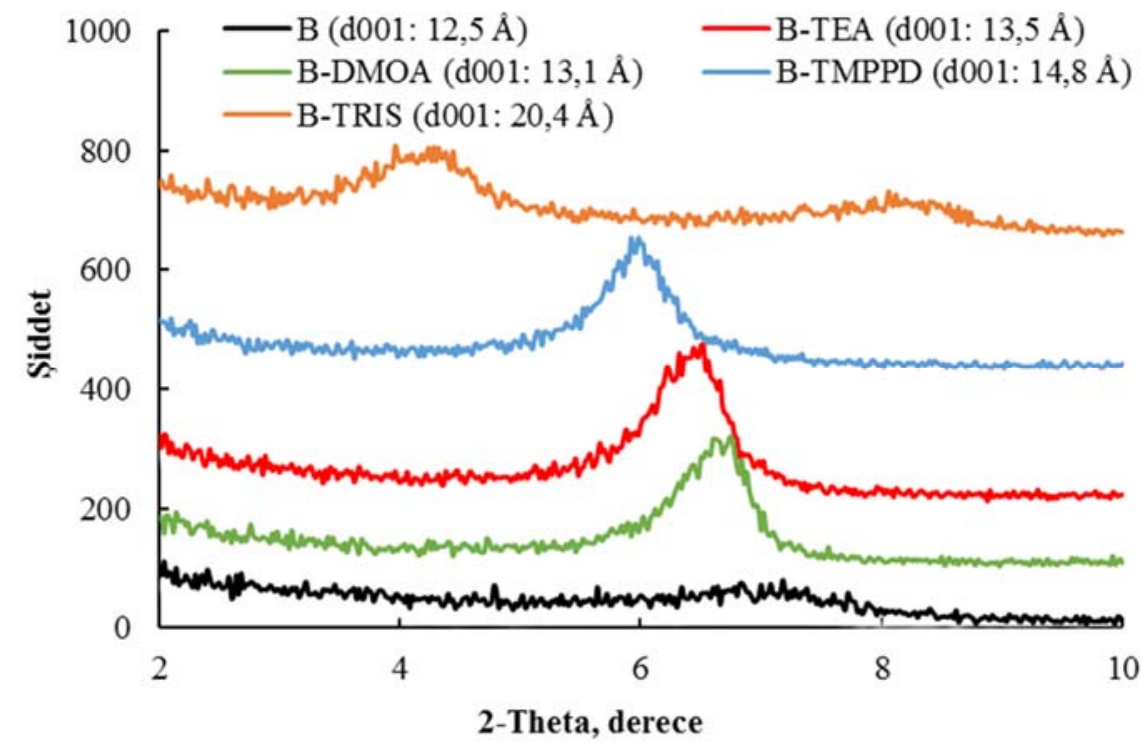

Şekil 1. Bentonit ve organobentonitler için XRD desenleri (XRD patterns of bentonite and organobentonites)

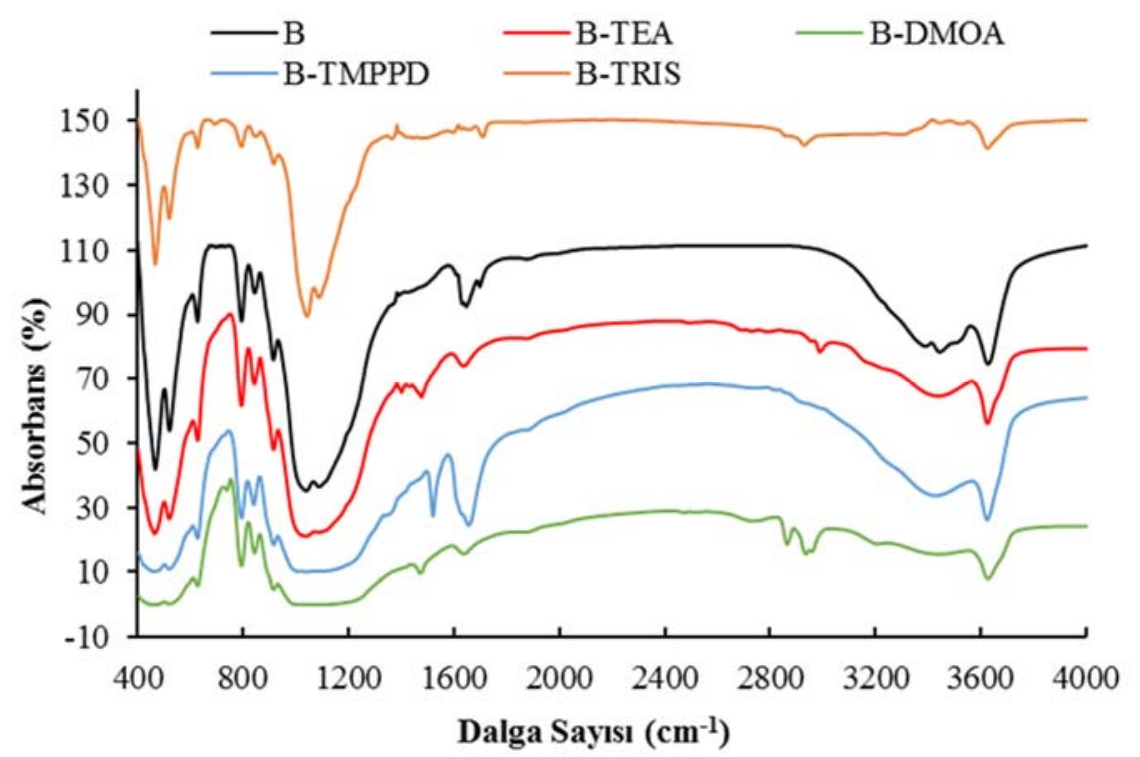

Şekil 2. Bentonit ve organobentonitler için FTIR spektrumları (FTIR spectra of bentonite and organobentonites) 
$\% 0,794, \% 1,42$ ve $\% 0,385$ olarak elde edilmiştir. Bu bileşiklerin molekül kütleleri göz önünde bulundurularak Eş. 1'e göre yapılan hesaplamalar, gram organobentonit başına modifikasyon bileşiği miktarının sırasıyla $47,9 \mathrm{mg}$ TEA, 89,0 mg DMOA, 83,2 mg TMPPD ve 33,3 mg TRIS olduğunu ortaya koymuştur.

$(\mathrm{mg} \mathrm{A} / \mathrm{g} \mathrm{B})=(\%$ azot $/ 100 \mathrm{~g} \mathrm{~B}) \times$

$\left(\right.$ Mol kütlesi $i_{\mathrm{A}} /$ Mol kütlesi $\left.{ }_{\text {azot }}\right) \times(1000 \mathrm{mg} / 1 \mathrm{~g})$

Burada A; modifikasyon bileşiğini, B ise organobentonit yapısını temsil etmektedir. Şekil 3'deki termogramlar incelendiğinde $800^{\circ} \mathrm{C}^{\prime}$ ye kadar toplam kütle kaybının bentonit için \%8,5, B-TEA için \%10,9, B-DMOA için
\%13,4, B-TMPPD için \%11,7 ve B-TRIS için \%10,6 olduğu görülmektedir. $\mathrm{Bu}$ noktada elementel analiz sonuçları ile termogravimetrik analiz sonuçlarının uyumlu olduğu ifade edilebilir. Ayrıca organobentonitlere ilişkin termogramların bentonitin termogramından farkli termal bozunma basamakları içermeleri ve bu basamaklardaki farklı oranlardaki kütle kayıpları (Tablo 1), modifikasyon süreçlerinin başarısını gösteren bir diğer önemli bulgudur. Bentonit ve organobentonitler için, yaklaşık $60-200^{\circ} \mathrm{C}$ aralığında gerçekleşen kütle kaybı basamağı yapılardaki yüzeyde adsorplanmış suyun kaybına işaret etmektedir. Bentonitin yaklaşık $600^{\circ} \mathrm{C}$ 'ye kadar termal kararlılığını hemen hemen koruduğu, ardından bu sicaklığın üzerinde tabakalar üzerinde bulunan $-\mathrm{OH}$ gruplarının

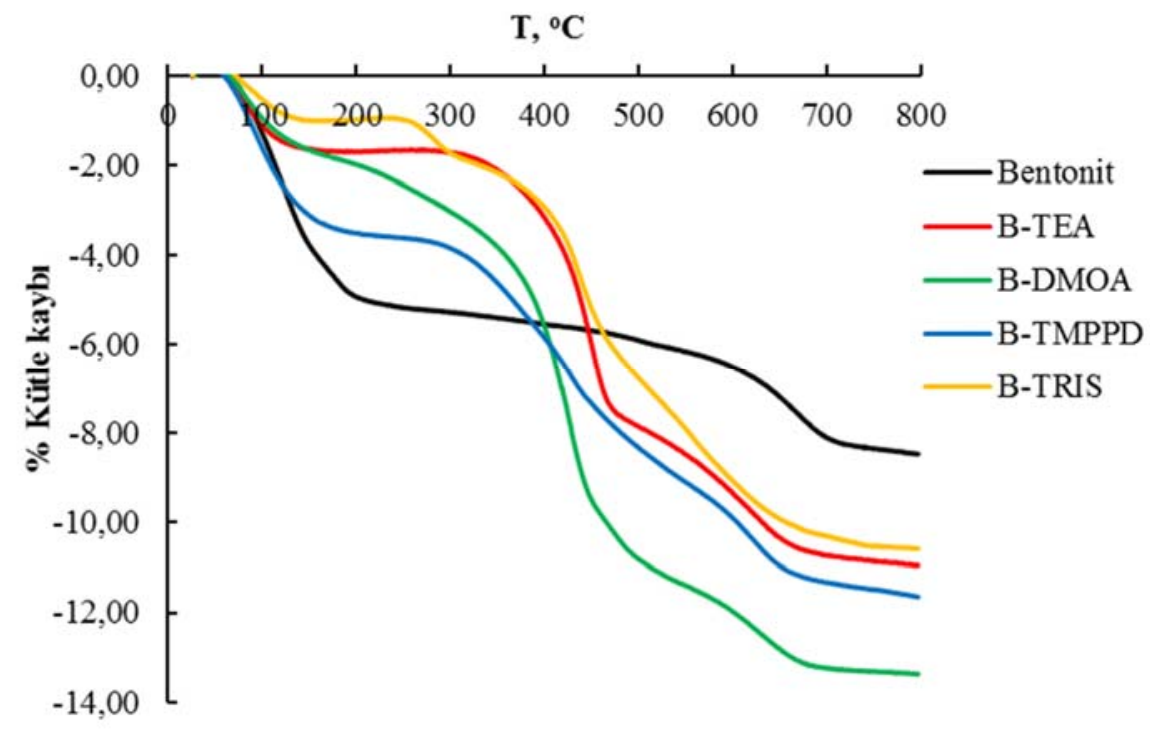

Şekil 3. Bentonit ve organobentonitlere ait termogramlar (Thermograms of bentonite and organobentonites)

Tablo 1. TGA sonuçları (TGA results)

\begin{tabular}{|c|c|c|c|c|}
\hline Katk1 & Termal süreç & $\begin{array}{l}\text { Sicaklık aralığ } 1 \\
\left({ }^{\circ} \mathrm{C}\right)\end{array}$ & $\begin{array}{l}\text { Kütle kayb1 } \\
(\%)\end{array}$ & $\begin{array}{l}800^{\circ} \mathrm{C}^{\prime} \text { deki } \\
\text { kül miktarı } \\
(\%)\end{array}$ \\
\hline \multirow{3}{*}{ Bentonit } & Su buharlaşma & $60-195$ & 5,1 & \multirow{3}{*}{8,5} \\
\hline & Termal bozunma & $580-670$ & 2,9 & \\
\hline & Su buharlaşma & $60-140$ & 1,9 & \\
\hline \multirow[t]{3}{*}{ B-TEA } & Birinci termal bozunma basamağ1 & $310-470$ & 5,3 & \multirow{3}{*}{10,9} \\
\hline & İkinci termal bozunma basamağı & $475-660$ & 3,7 & \\
\hline & $\mathrm{Su}$ buharlaşma & $60-200$ & 2,1 & \\
\hline \multirow[t]{3}{*}{ B-DMOA } & Birinci termal bozunma basamağ1 & $210-450$ & 7,9 & \multirow[t]{3}{*}{13,4} \\
\hline & İkinci termal bozunma basamağı & $460-680$ & 3,1 & \\
\hline & Su buharlaşma & $60-200$ & 3,8 & \\
\hline \multirow[t]{3}{*}{ B-TMPPD } & Birinci termal bozunma basamağ1 & $280-440$ & 3.6 & \multirow[t]{3}{*}{11,7} \\
\hline & İkinci termal bozunma basamağ1 & $450-680$ & 3.5 & \\
\hline & Su buharlaşma & $60-150$ & 1,0 & \\
\hline \multirow[t]{3}{*}{ B-TRIS } & Birinci termal bozunma basamağ1 & $240-320$ & 0,9 & \multirow[t]{3}{*}{10,6} \\
\hline & İkinci termal bozunma basamağı & $330-490$ & 3,6 & \\
\hline & $\begin{array}{l}\text { Üçüncü termal bozunma } \\
\text { basamağ1 }\end{array}$ & $500-710$ & 4,2 & \\
\hline
\end{tabular}


dehidroksilasyonu ile termal olarak bozunduğu ve yaklaşık $\%$ or,9 oranında ikinci bir kütle kaybına uğradığ 1 görülmektedir. Diğer yandan B-TRIS hariç diğer tüm organobentonitlerin iki termal bozunma basamağına sahip olduğu görülmektedir. Kuşkusuz bu durum, modifikasyon bileşiklerinin yapısal farklılıklarından ve bentonit yapısı ile etkileşim düzeylerinin faklı olmasından kaynaklanmaktadır.

\subsection{Sert Poliüretan Köpük Nanokompozitlerin}

Karakterizasyonu

(Characterization of Rigid Polyurethane Foam Nanocomposites)

Şekil 4'te farklı oranlarda B-TEA ve B-TRIS katk1lı SPKN'lere ilişkin SAXS desenleri verilmiştir. B-TEA için katk1 miktarı $\% 5$ ve üzerine çıktığında 2-Theta=1-15 aralığında kırınım piki gözlenmekteyken, B-TRIS için \%7 katkılamaya kadar herhangi bir kırınım pikine rastlanmamaktadır. Desenlerde kırınım piki gözlenmemesi montmorillonit tabakalarının poliüretan matriks içerisinde eksfoliyasyonuna işaret eder ve tabakaların polimer zincirleri arasında pul pul dağıldı ̆̆ 1 söylenebilir. Bu iyi bir kompozit sistem için önemli bir gerekliliktir. Yaklaşık 2Theta $=6^{\circ}$ 'de çok belirgin olmamakla birlikte gözlemlenen kırınım pikleri ise daha yüksek katkı miktarlarında eksfoliye yapı ile birlikte interkale kompozit yapısının oluşumunu ifade etmektedir. Diğer yandan SAXS desenlerinden, BTRIS'in B-TEA'ya kıyasla polimer matriksi içerisinde daha iyi dağıldığı sonucu çıkartılabilir. B-TRIS'in polimerik
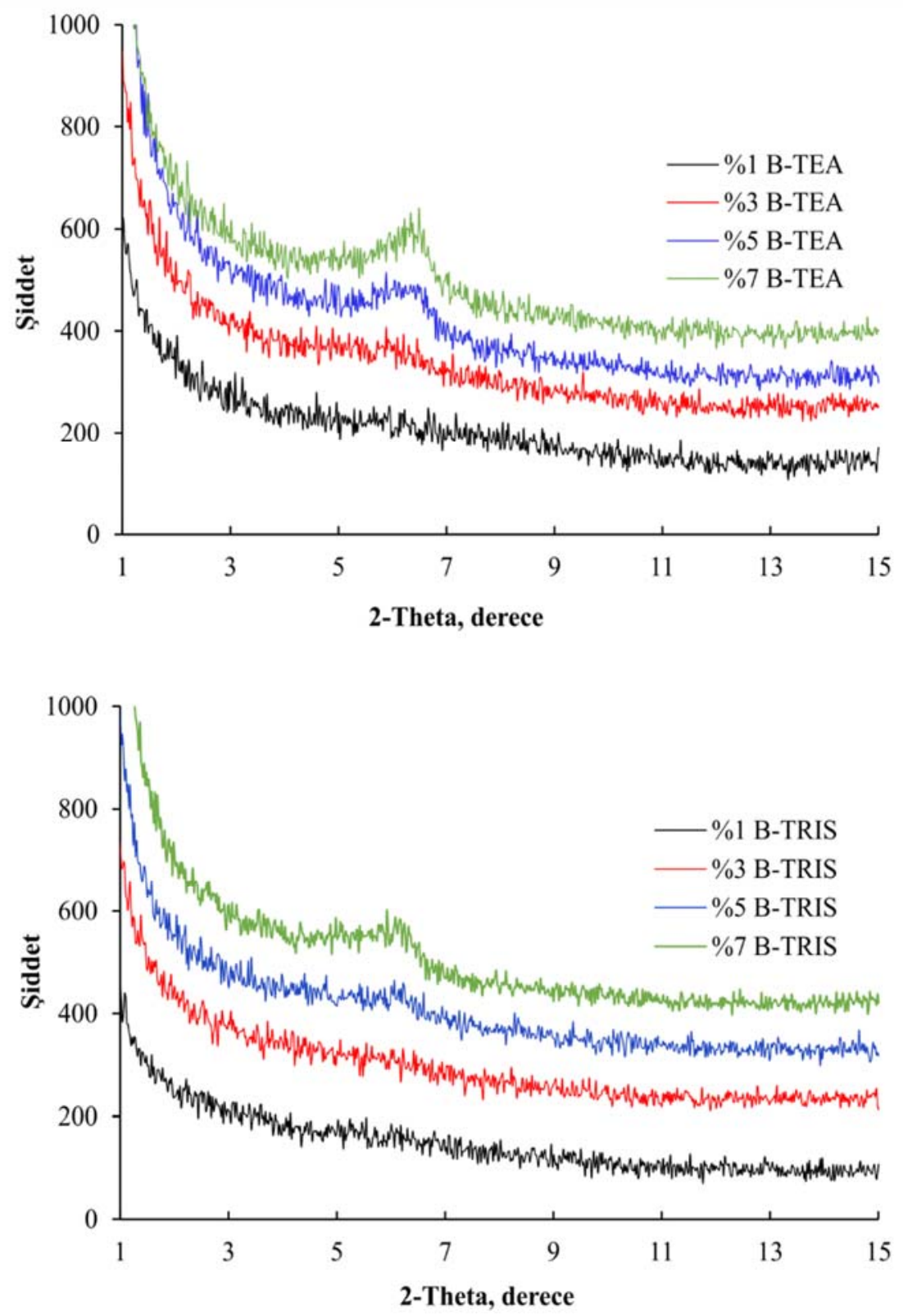

Şekil 4. Farklı oranlarda B-TEA ve B-TRIS katkılı SPKN'lere ilişkin SAXS desenleri (SAXS patterns of rigid polyurethane foam nanocomposites containing different ratio of B-TEA or B-TRIS) 
matriks içerisinde daha iyi dağılımının, köpük oluşumu sırasında izosiyanat bileşiği ile reaksiyon verebilecek fonksiyonel grup sayısının fazla olmasından kaynaklandığı düşünülmektedir. Literatürde, modifikasyon bileşiğindeki fonksiyonel grup türünün ve sayısının killerin poliüretan matriks içerisindeki dağılımını etkilediğini ifade eden çalışmalara rastlanmaktadır [14]. Farklı oranlarda BTMPPD katkılanmış SPKN'lere ait SEM görüntüleri Şekil 5 'te verilmiştir. Köpüklere ilişkin ortalama hücre boyutları bu görüntüler üzerinden hesaplanmıştır. Görüntüler incelendiğinde katkı miktarına bağlı olarak hücre boyutlarında meydana gelen azalma net bir biçimde görülmektedir. Hücre boyutunun küçülmesi, SPK'lerin hem 1s1l yalıtım performanslarını hem de mekanik özelliklerini olumlu yönde etkiler [15]. Şekil 6 ve Tablo 2'de ise SPKN'ler için katkı miktarına bağlı olarak sırasıyla ortalama hücre boyutundaki değişim ve kapalı hücre içeriği değişimi verilmiştir. Eksfoliye montmorillonit tabakaları, buharlaşmaya başlayan şişirici gaz moleküllerinin çekirdeklenmesi, gaz baloncuklarının oluşumu ve bunların birleşerek büyümesi sürecine heterojen çekirdeklenme ajanı olarak katkı verirler. Tabaka sayısındaki artışla birlikte çekirdeklenme yüzeyi artar, baloncuklar (dolayısıyla da hücreler) küçülür ve sayıları artar. $\mathrm{Bu}$ mekanizma katkı varlığında ortalama hücre boyutunda meydana gelen düşüşü açıklar [16]. Tüm nanokompozit köpükler için katkı miktarındaki artış ile birlikte ortalama hücre boyutu beklendiği gibi azalmıştır. SPK için ortalama hücre boyutu $601 \mu \mathrm{m}$ iken, $\% 7$ oranında B-TMPPD varlığında bu değer yaklaşık \%58 oranında azalarak $255 \mu$ m'ye düşmüştür. Bentonit ve diğer organobentonitler ile aynı oranda katkılama yapıldığında ortalama hücre boyutundaki değişim
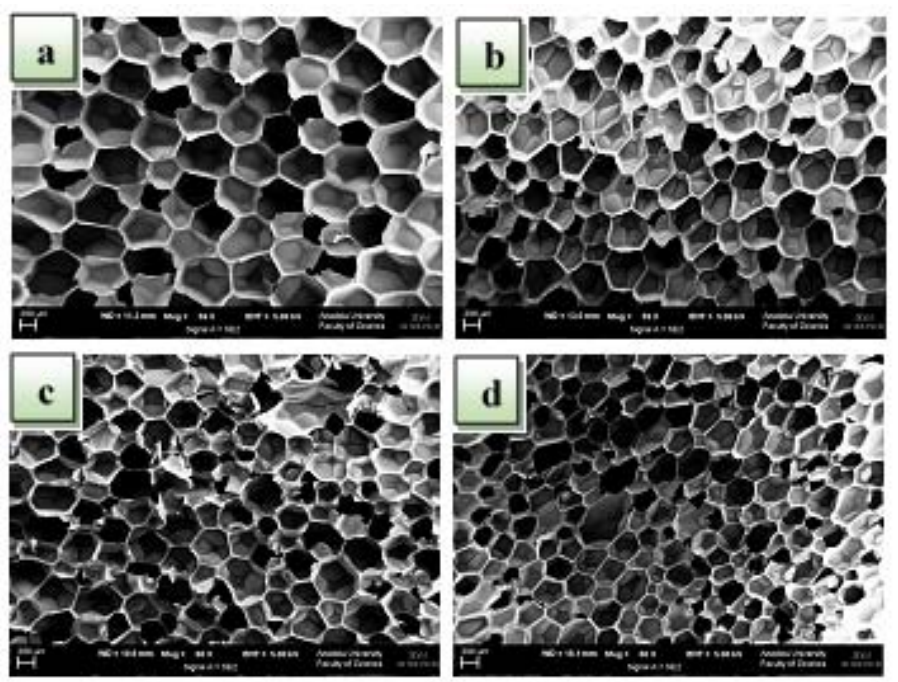

Şekil 5. a) \%1 b) \%3 c) \%5 ve d) $\% 7$ oranlarında B-TMPPD katkılı SPKN'lerin SEM görüntüleri (SEM images of rigid polyurethane foam nanocomposites containing the ratio of a) $\% 1$ b) $\% 3$ c) $\% 5$ ve d) $\% 7$ of B-TMPPD)

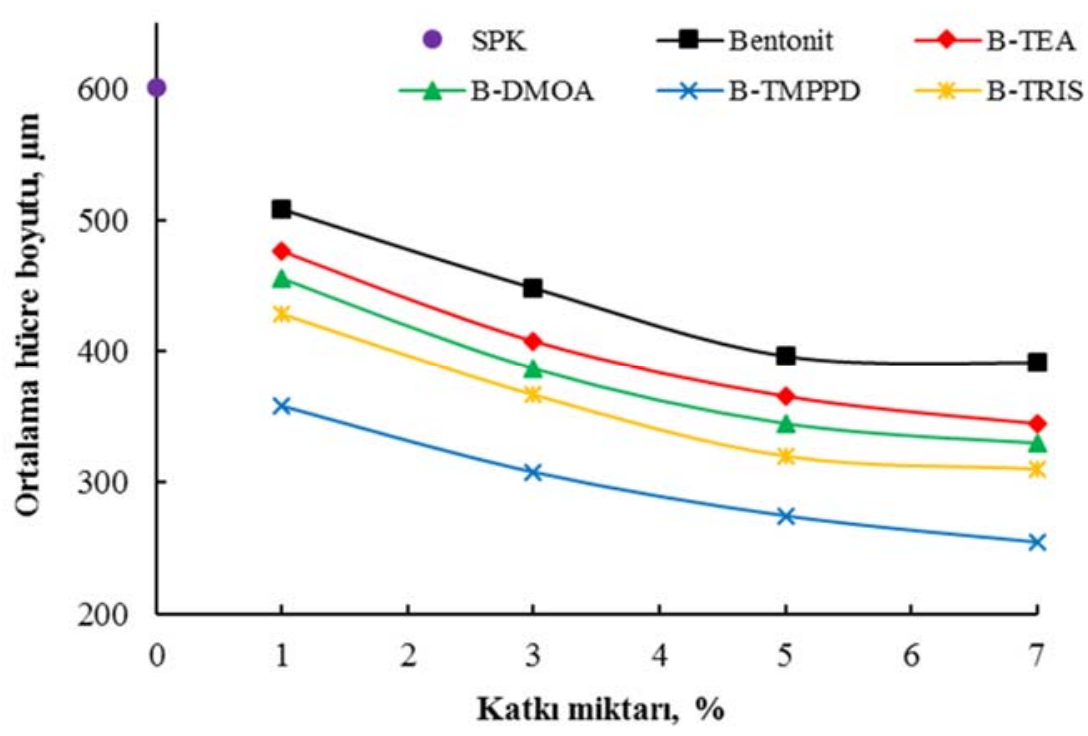

Şekil 6. SPKN'ler için katkı miktarına bağlı olarak ortalama hücre boyutlarındaki değişim (The variation of the average cell size of rigid polyurethane foam nanocomposites with the amount of additive) 
şu şekilde olmuştur: Bentonit için $391 \mu \mathrm{m}$, B-TEA için 345 $\mu \mathrm{m}$, B-DMOA için $330 \mu \mathrm{m}$ ve B-TRIS için $310 \mu \mathrm{m}$. Köpükler için bir diğer önemli parametre de kapalı hücre içeriğidir. Yüksek yüzdede kapalı hücre içeriği, köpüğün hem 1sıl yalıtım performansını hem de mekanik özelliklerini olumlu etkiler [17]. Literatürde kil katkılarının hücre açıcı özellik gösterdiği çalışmaların yanısıra, kapalı hücre oranında artışa neden olduğunu gösteren çalışmalar da bulunmaktadır [18]. Bu çalışma kapsamında elde edilen
SPKN'ler için kapalı hücre içeriği \%88-93 aralığında değişmiş, bu miktar daima SPK'nin kapalı hücre içeriğinden $(\% 87,8)$ daha yüksek olmuştur. SPKN'ler için katkı miktarındaki artış ile birlikte ısıl iletkenlik değerleri de azalmıştır. SPK için 23,36 mW/m.K olan ısıl iletkenlik, \%7 oranında bentonit, B-TEA, B-DMOA, B-TMPPD ve BTRIS katkılanmış SPKN'ler için sırasıyla 22,24, 22,01, $21,48,20,99$ ve $21,26 \mathrm{~mW} / \mathrm{m} . \mathrm{K}$ olmuştur (Şekil 7). Is1l iletkenlikte meydana gelen bu azalmanın, ortalama hücre

Tablo 2. SPKN'ler için katkı miktarına bağlı olarak kapalı hücre içeriğindeki değişim SPK için kapalı hücre içeriği: $\% 87,8$ (The variation of the closed cell content of rigid polyurethane foam nanocomposites with the amount of additive The closed cell content of rigid polyurethane foam: $87.8 \%$ )

\begin{tabular}{lll}
\hline Katk1 & Katk1 miktarı, \% & Kapalı hücre içeriği, \% \\
\hline \multirow{3}{*}{ Bentonit } & 1 & 89,2 \\
& 3 & 90,8 \\
& 5 & 91,7 \\
B-TEA & 7 & 91,8 \\
& 1 & 89,1 \\
& 3 & 89,3 \\
B-DMOA & 5 & 90,3 \\
& 7 & 90,8 \\
& 3 & 89,9 \\
B-TMPPD & 5 & 91,2 \\
& 7 & 91,5 \\
& 1 & 91,6 \\
& 5 & 89,5 \\
B-TRIS & 7 & 91,3 \\
& 1 & 91,8 \\
& 3 & 92,8 \\
& 5 & 89,8 \\
& 7 & 90,2 \\
\end{tabular}

Tablo 3. SPKN'ler için katkı miktarına bağlı olarak yoğunluklarındaki değişim SPK için yoğunluk: 35,17 kg/m³ (The variation of the density of rigid polyurethane foam nanocomposites with the amount of additive The density of rigid polyurethane foam: $35.17 \mathrm{~kg} / \mathrm{m}^{3}$ )

\begin{tabular}{lll}
\hline Katk1 & Katk1 miktarı, $\%$ & Yoğunluk, $\mathrm{kg} / \mathrm{m}^{3}$ \\
\hline \multirow{3}{*}{ Bentonit } & 1 & 36,3 \\
& 3 & 36,7 \\
& 5 & 36,8 \\
B-TEA & 7 & 37,8 \\
& 1 & 36,7 \\
& 3 & 37,3 \\
B-DMOA & 5 & 36,5 \\
& 7 & 36,1 \\
& 1 & 36,9 \\
B-TMPPD & 3 & 37,5 \\
& 5 & 37,1 \\
& 7 & 36,9 \\
& 1 & 36,0 \\
B-TRIS & 5 & 36,4 \\
& 7 & 36,9 \\
& 1 & 37,1 \\
& 3 & 36,0 \\
& 5 & 36,3 \\
& 7 & 36,4 \\
\hline
\end{tabular}




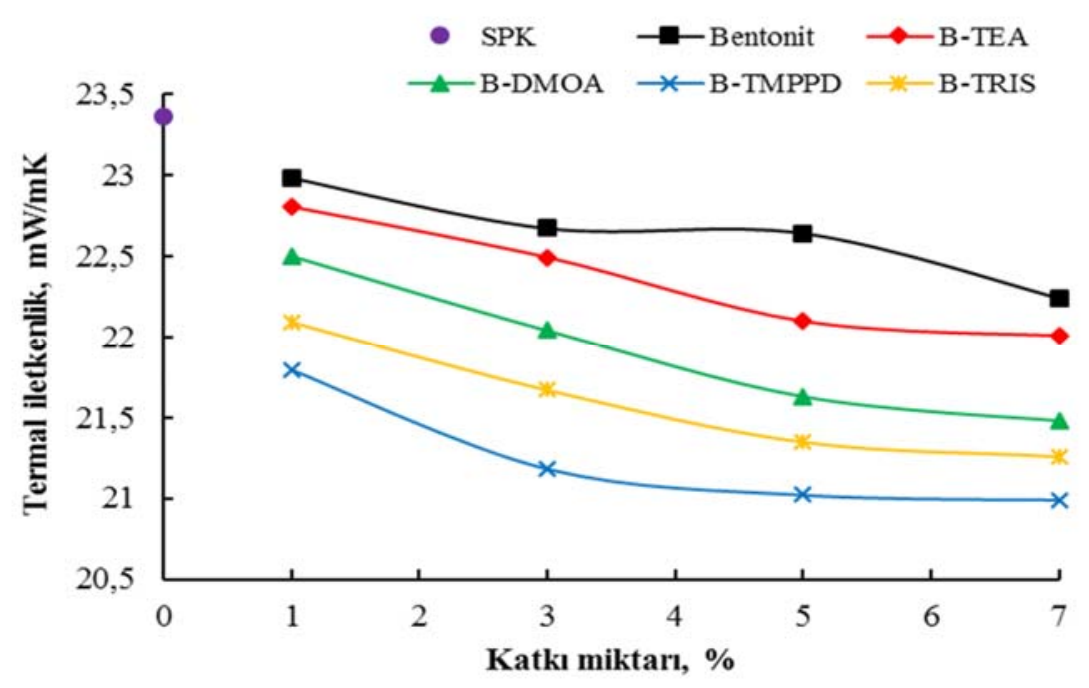

Şekil 7. SPKN'ler için katkı miktarına bağlı olarak 1sıl iletkenliklerindeki değişim

(The variation of the thermal conductivity of rigid polyurethane foam nanocomposites with the amount of additive)

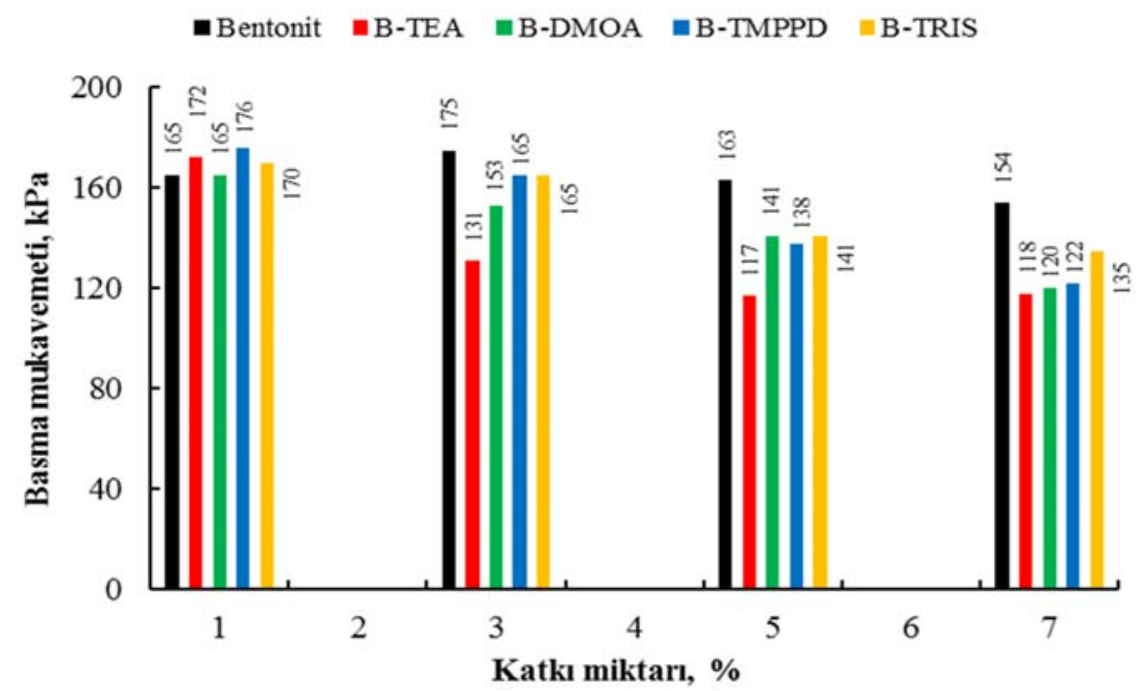

Şekil 8. SPKN'ler için katkı miktarına bağlı olarak basma mukavemetlerindeki değişim SPK için basma mukavemeti: 163 $\mathrm{kPa}$ (The variation of the compressive strength of rigid polyurethane foam nanocomposites with the amount of additive The compressive strength of rigid polyurethane foam: $163 \mathrm{kPa}$ )

boyutundaki düşüş ile birlikte kapalı hücresel yapının da korunmasından kaynaklandığı açıktır. Tablo 3 ve Şekil 8 incelendiğinde, SPKN'ler için yoğunluk değerlerinin katkı miktarındaki artışla birlikte yükseldiği, buna karşın basma mukavemeti değerlerinin \%1'den daha yüksek katkılama oranlarında azaldığı görülmektedir. Bu durum, \%1'den daha yüksek katkılama oranlarında, basma mukavemeti değerini yükselten yoğunluk artışından ziyade, basma mukavemeti değerini azaltan hidrojen bağı oluşumunun engellenmesi (kısmen de olsa) etkisinin basma mukavemeti üzerinde daha etkin olduğunu ortaya koymaktadır [19].

\section{SIMGELER (SYMBOLS)}

$\mathrm{d}_{001}:$ Temel tabakalar arası açıklık

$2 \theta:$ X-1şını kırınım açısı

\section{SONUÇLAR (CONCLUSIONS)}

$\mathrm{Bu}$ çalışmada; bentonitin amin ve hidroksil fonksiyonelliklerine sahip bileşikler ile modifikasyonu gerçekleştirilmiş, elde edilen organobentonitler FTIR, XRD, TGA ve elementel analiz yöntemleri ile karakterize edilmiştir. Bentonitin modifikasyonu, montmorillonit tabakaları arasında konumlanmış yer değiştirebilir iyonların, asidik ortamda kuaterner hale getirilmiş modifikasyon bileşiklerinin iyonları ile yer değiştirmeleri sağlanarak gerçekleştirilmiştir. Bentonitin 1,0 g'1 için modifikasyon bileşiği miktarları 0,474 mmol TEA, 0,566 mmol DMOA, $0,508 \mathrm{mmol}$ TMPPD ve 0,261 mmol TRIS olarak belirlenmiştir. Bentonit ve organobentonitler sert poliüretan köpük nanokompozit (SPKN) eldesinde katk1 olarak kullanılmış, katkılama poliol kütlesine kıyasla \%1, \%3, \%5 
ve $\% 7$ oranlarında yapılmıştır. SAXS sonuçları, B-TEA için $\% 5$ katkı oranına kadar, B-TRIS için ise $\% 7$ katkı oranına kadar montmorillonit tabakalarının poliüretan matriks içerisinde eksfoliasyonuna işaret etmektedir. Tabakaları arasında 3 adet hidroksil ve bir adet amin fonksiyonelliğine sahip TRIS moleküllerini içeren B-TRIS, polimer matriks içerisinde daha iyi dağılmıştır. Tüm katkılar köpügün ortalama hücre boyutunda ve 1s1l iletkenliğinde düşüşe neden olmuştur. Katkı miktarı arttıkça hem ortalama hücre boyutu hem de isıl iletkenlik azalmıştır. $\mathrm{Bu}$ anlamda, tüm organobentonitler bentonite kıyasla daha etkilidirler. SPK için ortalama hücre boyutu $601 \mu \mathrm{m}$ iken, $\% 7$ oranında bentonit, B-TEA, B-DMOA, B-TMPPD ve B-TRIS katkılanmış SPKN'ler için bu değer sırasıyla 391, 345, 330, 255 ve $310 \mu \mathrm{m}$ olmuştur. SPK için $23,36 \mathrm{~mW} / \mathrm{m}$.K olan $1 \mathrm{~s} 1 \mathrm{l}$ iletkenlik değeri, $\% 7$ oranında bentonit, B-TEA, B-DMOA, B-TMPPD ve B-TRIS katkılanmış SPKN'ler için sırasıyla $\% 4,8, \% 5,8, \% 8,0, \% 10,1$ ve $\% 8,9$ oranında düşürülmüştür. Katkı türüne ve miktarına bağlı olarak ortalama hücre boyutundaki azalış eğilimi ile 1sıl iletkenlikteki azalış eğilimi paralel olduğundan, 1sıl iletkenlik konusunda belirleyici temel etken ortalama hücre boyutundaki azalma olmuştur. TRIS, tetrafonksiyonel yapısı nedeniyle izosiyanat yapısı ile reaksiyona girme fonksiyonelliği yüksek bir bileşiktir. Bu durumun, B-TRIS'in organik karakterli polimer matriksi içerisindeki dağılımını olumlu etkilediği, dolayısıyla BTRIS katkılı SPKN'lerin ortalama hücre boyutu ve termal iletkenlik konularındaki performanslarının iyi olduğu düşünülmektedir. Diğer yandan, bifonksiyonel TMPPD'nin TRIS'e kıyasla daha baskın organik karakterinin, BTMPPD'nin B_TRIS'e kıyasla bahsi geçen noktalarda daha etkin bir performans göstermesinin nedeni olduğu düşünülmektedir. B-TEA ve B-DMOA katkılı SPKN'lerin daha düşük performanslarının sebebinin ise, TEA ve DMOA'nın hem fonksiyonel grup sayılarının azlığı hem de daha düşük organik nitelikleri olduğu düşünülmektedir. Kendi aralarında kıyaslandıklarında ise organik karakteri daha baskın bileşik ile modifiye edilmiş B-DMOA daha etkindir.

SPK için kapalı hücre içeriği \%87,8'dir ve katkılama ile birlikte bu içerik en fazla yaklaşık \%5,7 oranında artmıştır. Elde edilen sonuçlar; kapalı hücre içeriği üzerine, modifikasyon ajanı türünden ziyade bir çekirdeklenme ajanı olarak bentonite ve modifiye bentonit yapısının kullanılmış olmasının etkili olduğunu düşündürmektedir. Katk1 miktarındaki artış, kapalı hücre içeriğini daima arttırmaktadır. Ancak, değerlerin biribirine yakınlığı ve değişkenliği ajan türüne bağlı olarak değerlendirmeyi güç kılmaktadır. SPKN'lerin yoğunlukları SPK'nin yoğunluğundan daima fazla olmuş, en yüksek yoğunluk değeri $\% 7$ bentonit katk1lı SPKN için $37,8 \mathrm{~kg} / \mathrm{m}^{3}$ olarak belirlenmiştir. \%1 katkı içeren tüm SPKN'ler için basma mukavemeti değerleri SPK'ye kıyasla yüksek olmuş, katk1 miktarındaki artış ile birlikte mukavemet değerleri genellikle düşmüştür. Bentonit için mukavemet değeri ancak \%7 katk1 oranında SPK'nin değerinin altına düşmüştür. Organobentonitlerin aynı oranda katkılanması durumunda basma mukavemeti değerlerinin yaklaşı $120 \mathrm{kPa}$ civarına düştüğü görülmüştür. SPK yapılarının basma mukavemeti, biribirini örseleyen iki önemli etkinin yarışı sonucu ortaya çıkar: hücre küçülmesi ve yoğunluk artışının mukavemete olumlu etkisi ile hidrojen bağları aracılığıyla yapıya mukavemet sağlayan örgü yapısının kil tabakaları varlığında engellenmesi. $\mathrm{Bu}$ kapsamda SPKN'ler için basma mukavemetinin katkılama oranı arttıkça genellikle azalması, yoğunluk artışından ziyade örgü yapı oluşumunun kısmi olarak engellemesi durumunun bu mücadelede daha etkin olduğunu ortaya koymaktadır.

Sonuç olarak, 1sıl iletkenlik yaklaşık \%10 mertebelerinde azaltılmış, bununla birlikte basma mukavemeti değerleri ise iyileştirilmiş veya makul kabul edilebilecek seviyede tutularak korunmuştur. Bu sonuçlar, çalışma için hedeflenen performans kriterlerine ulaşıldığını ortaya koymakta olup, elde edilen SPKN'lerin endüstriyel anlamda da değerli olabileceği öngörülmektedir.

\section{TEŞEKKÜR (ACKNOWLEDGEMENT)}

Bu çalışmanın yazarları, 1406F323 numaralı proje çalışması kapsamındaki desteklerinden dolayı Anadolu Üniversitesi Bilimsel Araştırma Projeleri Komisyonu Başkanlığına teşekkür ederler.

\section{KAYNAKLAR (REFERENCES)}

1. Zhao C., Yan Y., Hu Z., Li L., Fan X., Preparation and characterization of granular silica aerogel/ polyisocyanurate rigid foam composites, Constr. Build. Mater., 93, 309-326, 2015.

2. Nazeran N., Moghaddas J., Synthesis and characterization of silica aerogel reinforced rigid polyurethane foam for thermal insulation application, J. Non-Cryst. Solids, 461, 1-11, 2017.

3. Saçak M., Polimer teknolojisi, Gazi Kitabevi, Ankara, Türkiye, 2013.

4. Harikrishnan G., Patro T.U., Khakhar D.V., Polyurethane foam-clay nanocomposites: Nanoclays as cell openers, Ind. Eng. Chem. Res., 45, 7126-7134, 2006.

5. Zarzyk I., Preparation and characterization of rigid polyurethane foams with carbamide and borate groups, Polym. Int., 65, 1430-1440, 2016.

6. Lee Y., Jang M.G., Choi K.H., Han C., Kim W.N., Liquid-type nucleating agent for improving thermal insulating properties of rigid polyurethane foams by HFC-365mfc as a blowing agent, J. Appl. Polym. Sci., 133, Article Number: 43557, 2016.

7. Kang M.J., Kim Y.H., Park G.P., Han M.S., Kim W.N., Park S.D., Liquid nucleating additives for improving thermal insulating properties and mechanical strength of polyisocyanurate foams. J. Mater. Sci., 45, 5412-5419, 2010.

8. Widya T., Macosko C.W., Nanoclay-modified rigid polyurethane foam. J. Macromol. Sci. B, 44, 897-908, 2005.

9. Pauzi N.N.P.N., Majid R.A., Dzulkifli M.H., Yahya M.Y., Development of rigid bio-based polyurethane foam reinforced with nanoclay, Compos. Part B-Eng., $67,521-526,2014$. 
10. Aydoğan B., Usta N., Investigation the effects of nanoclay and intumescent flame retardant additions on thermal and fire behaviour of rigid polyurethane foams, Journal of the Faculty of Engineering and Architecture of Gazi University, 30 (1), 9-18, 2015.

11. Erdem B., Heterohalkalı aromatik bileşiklerin doğal killere adsorpsiyonunun incelenmesi, Doktora Tezi, Anadolu Üniversitesi, Fen Bilimleri Enstitüsü, Eskişehir, 2010.

12. Tyan H.L., Liu Y.C., Wei K.H., Thermally and mechanically enhanced clay/polyimide nanocomposite via reactive organoclay, Chem. Mater., 11, 1942-1947, 1999.

13. Azzouz A., Platon N., Nousir S., Ghomari K, Nistor D., Shiao T.C., Roy R., OH-enriched organomontmorillonites for potential applications in carbon dioxide separation and concentration, Sep. Purif. Technol., 108, 181-188, 2013.

14. Chen T.K., Tien Y.I., Wei K.H., Synthesis and characterization of novel segmented polyurethane/clay nanocomposites, Polymer, 41, 1345-1353, 2000.
15. Danowska M., Piszczyk L., Strankowski M., Gazda M., Haponiuk J.T., Rigid polyurethane foams modified with selected layered silicate nanofillers, J. Appl. Polym. Sci., 130, 2272-2281, 2013.

16. Kang J.W., Kim J.M., Kim M.S., Kim Y.H., Kim W.N., Effects of nucleating agents on the morphological, mechanical and thermal insulating properties of rigid polyurethane foams, Macromol. Res., 17, 856-862, 2009.

17. Hebda E., Ozimek J., Raftopoulos K.N., Michalowski S., Pielichowski J., Jancia M., Pielichowski K., Synthesis and morphology of rigid polyurethane foams with POSS as pendant groups or chemical crosslinks, Polym. Adv. Technol., 26, 932-940, 2015.

18. Patro T.U., Harikrishnan G., Misra A., Khakhar D.V., Formation and characterization of polyurethanevermiculite clay nanocomposite foams. Polym. Eng. Sci. 48, 1778-1784, 2008.

19. Cao X., Lee L.J., Widya T., Macosko C., Polyurethane/clay nanocomposites foams: Processing, structure and properties, Polymer, 46, 775-783, 2005. 
